\title{
Local Governments and Local Waste Management in the Czech Republic: Producers or Providers?
}

\author{
Jana Soukopová, Daniel Klimovský
}

\begin{abstract}
Local governments are responsible for the delivery of a large variety of very different public services. The article is focused on two issues: 1) we try to discover whether the local governments in the Czech Republic prefer to be "producers" or "providers" of the waste-collection services; 2) we test and compare the efficiency of "production" and the efficiency of "provision", and for this purpose we take into account various factors, inter alia inter-municipal cooperation, the existence of hybrid organizations, economies of scale etc. A main goal is to find out what the local governments in the Czech Republic prefer if they decide on the delivery of local services linked to waste management and what factors are the most important ones from the perspective of their potential influence on efficiency. Concerning the data, we analyse linked open data on municipal solid waste expenditure collected by the Ministry of Finance of the Czech Republic and data relating to features of waste collection obtained via a questionnaire-based survey which was carried out at the turn of 2015-2016. The results of the presented analysis show a clear relationship of dependence between the inter-municipal cooperation and the relevant costs, and it confirms the assumption that the Czech local governments undoubtedly prefer the position of "providers" in the field of the local waste management. Paradoxically, the results show that neither internal nor external provision of waste-collection services is a key factor of cost-efficiency.
\end{abstract}

\section{Keywords}

local government, public utilities, local service delivery, waste management, intermunicipal cooperation 


\section{Introduction}

In general, local governments provide a large number of public utility services, which are delegated on them as part of their original and devolved powers. ${ }^{1}$ These services also include services linked to waste management, and the local governments in the Czech Republic are obligated to deliver them within their original powers. Over the past fifty years, the academic world has been discussing the manners in which various public utilities should be provided. Concerning the waste management, its services can be delivered either externally (e.g. contracting-out or outsourcing, when an external entity is authorized to deliver a public utility service) or internally (i.e. in-house delivery, when a public utility service is delivered by a local government itself). Although the efficiency of public utilities delivery is not a new research topic, it is true that the recent financial crisis has brought, inter alia, a kind of worldwide "research tsunami" aimed at the efficiency of delivery of public utilities at all levels of government (cf. Soukopová et al. 2016; Simões and Marques 2012). Both the scholars and practitioners have used to focus on various fiscal impacts, and these impacts have soon become one of the top research issues. Although most of the relevant researchers limited their research activities by focusing on national contexts, there have already been attempts to deliver comparative studies in this field (e.g. Wollmann 2011). However, a systematic research focused on the delivery of local public utilities still remains rather rare (e.g. Wollmann et al. 2016).

Nevertheless, the increasing importance of waste management and efficiency in public service delivery has led us to the state that they can be considered broadly discussed topic; both in terms of theory and practical experience (cf. Callan and Thomas 2001; Dijkgraaf and Gradus 2003; Ohlsson 2003; Bel and Costas 2006; Sørensen 2007; Bel and Mur 2009; Dijkgraaf and Gradus 2013; Zafra-Gómez et al. 2013; Gradus et al. 2014; Soukopová et al. 2014; Bel and Warner 2008; Soukopová et al. 2016). Regardless of this broad discussion, there is no general agreement whether the local governments should prefer to deliver their services as producers or providers. While some authors recommend direct in-house production of local services, there are others who show that the external provision of local services is a rather more efficient method of their delivery. Concerning the public utilities and their delivery, it must be stressed that "service provision" is not the same as "service production" (Oakerson 1999). Service provision is rather connected to political decisions (e.g. what service, to whom, under what conditions, what management and what control), and from this perspective, it is clear that despite the fact that local government is responsible for some service provision, it may be produced (e.g. by means of outsourcing) by some other entity (Oakerson 1999). From this perspective, it is not any surprise that there is a rich variety of various cooperation forms

1 These public utilities ensured by local governments include municipal services such as transport, waste and water management and maintenance of green spaces on the one hand, and social services such as the educational system on the other, etc. 
that are developed by the local governments, including the inter-municipal cooperation forms.

Our intention is to contribute to the ongoing academic discussion aimed at these issues, and therefore, a main goal of this article is to find out what the local governments in the Czech Republic prefer if they decide on the delivery of local services linked to waste management and what factors are the most important ones from the perspective of their possible influence on efficiency. Taking into account the fact that local waste-management expenditure is equal to more than $60 \%$ of the current environmental protection expenditure and on average accounted for $3 \%$ of the total current expenditure of the local governments in the Czech Republic in the period of 2011-2015, one can consider the Czech experience an interesting case, which might provide suitable empirical data as well as important insights.

Within this context, our article is focused on the waste management at the local level in the Czech Republic; and we used empirical data from the South Moravian Region ${ }^{2}$ for the purpose of analysis. Our research questions are as follows:

RQ1: What position do the Czech local governments prefer in the field of waste management?

Basically, there are two possible positions for any local government which deliver local services. Either it is in the position of producer, or it is in the position of provider. Taking into account the fact that due to the highly fragmented municipal structure the inter-municipal cooperation forms are broadly used measures (e.g. Soukopová et al. 2016), we can assume that most of the local governments collaborate with the others also in the field of local waste management and prefer the position of providers.

RQ2: How does the efficiency of production in the field of local waste management differ from the efficiency of provision in the same field?

Some empirical studies from the Czech Republic and/or Slovakia (both countries belong to the most fragmented European countries) brought ambivalent results so far (e.g. Soukopová and Malý 2013). From this point of view, it is difficult to formulate any clear assumption. However, most of those scholars favour internal production, and therefore we can expect internal production to be more efficient than external provision.

2 The South Moravian Region with a population of about 1,140,000 inhabitants and an area size covering 719,555 ha lies in the southeast part of the Czech Republic, and it borders, inter alia, on Austria and Slovakia. Brno, the second largest city of the Czech Republic, is located in this region, and it is considered an important judiciary city, a university city, as well as a Central European trade-fair centre). The South Moravian Region is subdivided in seven counties (namely Blansko, Brno-city, Brno-countryside, Břeclav, Hodonín, Vyškov and Znojmo) in terms of administrative division. 
RQ3: Is the "production-provision" dilemma, namely the mode of production and the form of provision, key factors of cost-efficiency in the field of local waste management?

Although we assume that both factors can play a significant role, we must state that our assumption is rather based on intuition than on any clear previous empirical studies. The point is that the research in this field is unsystematic, and it requires much higher interest from relevant researchers.

In other words, there are two fundamental research issues:

1) we investigate whether the local governments in the Czech Republic prefer either the position of "producer" or rather the position of "provider" in the field of local waste management; and

2) we measure the differences between the efficiency of "production" and the efficiency of "provision" in the field of local waste management, taking into account other factors influencing cost-efficiency, such as economies of scale, inter-municipal cooperation, hybridity, etc.

Concerning the waste-management field, we have decided to focus on this public utility because there is a lack of research in this area in the Czech Republic. We believe that the Czech experience can contribute to the overall academic debate, since it provides interesting results linked to an extremely fragmented country, where the average size of a local government is below 1,800 citizens (Csachova and Nesorová-Dická 2011). In addition, thanks to the fact that the research in this field has a strong tradition in the OECD countries and the relevant data are available, we try to compare our results with the results of other authors.

\subsection{Delivery of local services: "production" and "provision" and other factors influencing the cost-efficiency of waste-management expenditure}

In practice, the local governments have a set amount of power at their disposal, and they are responsible for certain tasks (e.g. delivery of a certain number of services). However, before local service delivery, they must always decide whether they want to be producers of them, or whether they rather prefer the position of providers without direct production of these services. And while the decision is being made, they need to take into account the pros and cons of different options. On this matter, there are dozens of factors which influence their decision, but recently especially the factors that might explain the efficiency of such delivery are broadly used in order to support or refuse the options.

Within this context, Oakerson (1999) distinguishes several options for local service delivery: 1) in-house provision/production: rendering of local services is in the hands of a local government; 2) coordinated provision/production: lo- 
cal governments render the local services after mutual consultations, but they do not establish any joint institution; 3) conferring a duty to another entity of local government: a selected local government is authorized to render local services on behalf of other local government/s; 4) joint provision/production of a service by a partially autonomous institution: the services are rendered by a semi-autonomous agency which has been established by cooperating local governments; 5) private contracting: there is an agreement/contract between a local government and an external private service producer, and the services are outsourced; 6) joint provision of a service by an autonomous legal person governed by public law: local governments establish an independent public-law agency which is equipped with relevant decision-making and managerial powers, and after the establishment the agency is responsible for the rendered services; 7) franchising: a local government transfers the right to both produce and sell a local service to a private commercial producer, and the producer renders the service; 8 ) vouchering: the citizens are provided with vouchers which have been granted by their local government, and they have the right to choose a producer who consequently renders the service (Oakerson 1999, 17-18). In the first four types, providers can be the same entities as the producers. However, in the latter types, the position of provider does not overlap with the position of producer if one speaks about local public services. The point is that there is no generally accepted conclusion which could confirm higher efficiency of any of these options in comparison with the others.

Concerning the existing research results, the delivery of local public utilities became a pretty hot research issue in recent years, although one can find interesting studies in this field with much older dates of publication. The relation between the manner of ensuring public utility services and effectiveness was studied by a number of "Western" authors, first mostly in the USA, Canada and the UK (Hirsch 1965; Stevens 1978; McDavid 1985; Domberger et al. 1986; Callan and Thomas 2001), later also in European countries, for example in Spain (Bel and Costas 2006; Bel et al. 2010; Bel et al. 2014; Benito et al. 2014), the Netherlands (Dijkgraaf and Gradus 2003 2007; Gradus et al. 2014, 2016), Italy (Lombrano 2009), etc. Recently, the debate was also opened in the "Eastern European" countries, and a number of studies was conducted in the countries of Central and Eastern Europe (for example Nemec et al. 2005, 2012; Ochrana et al. 2007; Mikušová Meričková and Nemec 2013, Soukopová and Malý 2013; Mikušová Meričková et al. 2014).

As regards the evaluation of waste-management expenses, the discussion about the cost-efficiency of waste-management services was also mostly related to the analysis of the effect of the form of provision (internal/external) and the mode of production (public/private/mix) (Stevens 1978; McDavid 1985; Szymanski 1996; Reeves and Barrow 2000; Bel and Warner 2008, Benito et al. 2015 etc.). These studies have different natures. However, in those of empirical nature, their authors usually use a steady list of factors which contains 1) the quantity of waste generated in the local government, expressed in kilos per capita (output); 2) the population 
density; 3) the recycling level; 4) the existence of economies of scale; and 5) the location of landfills and transportation costs. Their results suggest that it is difficult to determine which form of provision and mode of production of local public utilities, especially waste management services, is better.

Table 1 shows that the form of provision was dealt with rather in older/earlier studies that were, however, mostly accompanied by analyses of the effect of a mode of production on waste-management expenditure. Results of the studies mostly point out that contracting and outsourcing/external provision is cheaper than internal provision of waste-management services. Only Hirsch (1965) demonstrates with regard to the local governments in the USA that from the point of view of the waste-management expenditure the difference between outsourcing and internal provision is not significant. Table 1 also shows that only 3 studies published by 2000 stated that private production is cheaper than public one. On the contrary, more recent studies rather deal with the mode of service production than the form of service provision, and they do not find any significant differences between private and public service production. The comparison of the results of studies conducted until 2010 was done by Bel et al. (2010) by means of meta-regression analysis. The results of this meta-regression analysis showed that on average it was private rather than public production of waste management services that effected a decrease of expenses (Bel et al. 2010). The results of Bel et al. (2010) also showed that lower costs depended on the characteristics of services, the geographic area or the time period of the studies.

On the contrary, the most recent studies show that although outsourcing can reduce municipal waste-management expenditure, public production is usually cheaper than private production (Bel et al. 2011) due to collaborative providing of public utility services by multiple local governments when an optimal scope of production and economies of scale is achieved. This is one of the reasons why the studies focused on the form of provision and mode of production were recently connected not only with an analysis of these factors but also the effect of the economies of scale or inter-municipal cooperation.

The debate concerning the form of provision and the mode of production of public utilities was also opened in the Central and Eastern European countries during the period of transformation; a number of studies were conducted there in the Czech Republic and Slovakia (e.g. Nemec et al. 2005; Pavel and Sičáková-Beblavá 2008; Ochrana and Nekola 2009; Nemec et al. 2012; Mikušová Meričková and Nemec 2013; Soukopová and Malý 2013; Mikušová Meričková et al. 2014; Soukopová and Vaceková 2015, Soukopová et al. 2016) and there are several other sources of data obtained under the conditions of Central and Eastern Europe (for example Lember 2004; Grafenauer and Klarić 2011). Most of these studies, however, do not deal with waste management; see Table 2 , which presents only the studies dealing with waste-management-related issues and their results. 
It is obvious from Table 2 that research in the Czech Republic (and/or Slovakia) varies regarding conclusions, and results are often ambiguous. Most of the studies are also dedicated rather to the issues related to the form of provision of waste-management services than the mode of service production. This is one of the reasons why in the following sections we focus on these factors and we try to explore whether a synergic effect could be observed in the case of outsourcing and public production or outsourcing and private production. At the same time, our analysis is focused on the impact of other factors, which were identified by other scholars who dealt with cost-efficiency of waste management services. Last but not least, the parametric approach is used in the following analysis, which concurrently enables to use the evaluation of whether this is really a statistically significant explanatory variable (this approach is frequently used in similar international studies).

\section{Data and methodology}

The research has been performed with respect to data collected for the year 2015, and the sample consists of 673 municipalities/local governments located in the South Moravian Region. ${ }^{3}$ The linked open data on municipal areas and populations from the Czech Statistical Office (CZSO) and the linked open data on municipal solid waste expenditure (MSWE) from MONITOR, the specialized information portal of the Ministry of Finance of the Czech Republic, have been used for the analysis. The data relating to waste collection companies, inter-municipal cooperation, scale economies, hybridity etc. have been obtained via a questionnaire-based survey. The survey was carried out from September 2015 to the end of January 2016.

To achieve the standard data distribution, it was necessary to clean the data. The standard distribution was achieved after the data had been cleaned by $2 \%(1 \%$ at each side). The data set after the sample cleaning contains 658 municipalities/local governments.

A statistical analysis of data (using the basic descriptive statistics in relation to the studied factors) is performed in the introduction to the chapter together with the cluster analysis for individual-size categories of municipalities/local governments. Subsequently, in order to make it possible to compare the results of the research with international parametric (econometric) studies (for example Bel and Costas 2006; Bel and Mur 2009, Bel and Fageda 2011; Dijkgraaf and Gradus 2013, etc.), the regression analysis (OLS model) is used as in the case of the above specified studies. The basic function of expenses on municipal waste management in relation to the manner of ensuring and the form of providing waste-management services and other factors takes the following form:

3 There are 673 municipalities in the South Moravian Region. Only data of 3 municipalities with populations less than 10 inhabitants were not obtained. 


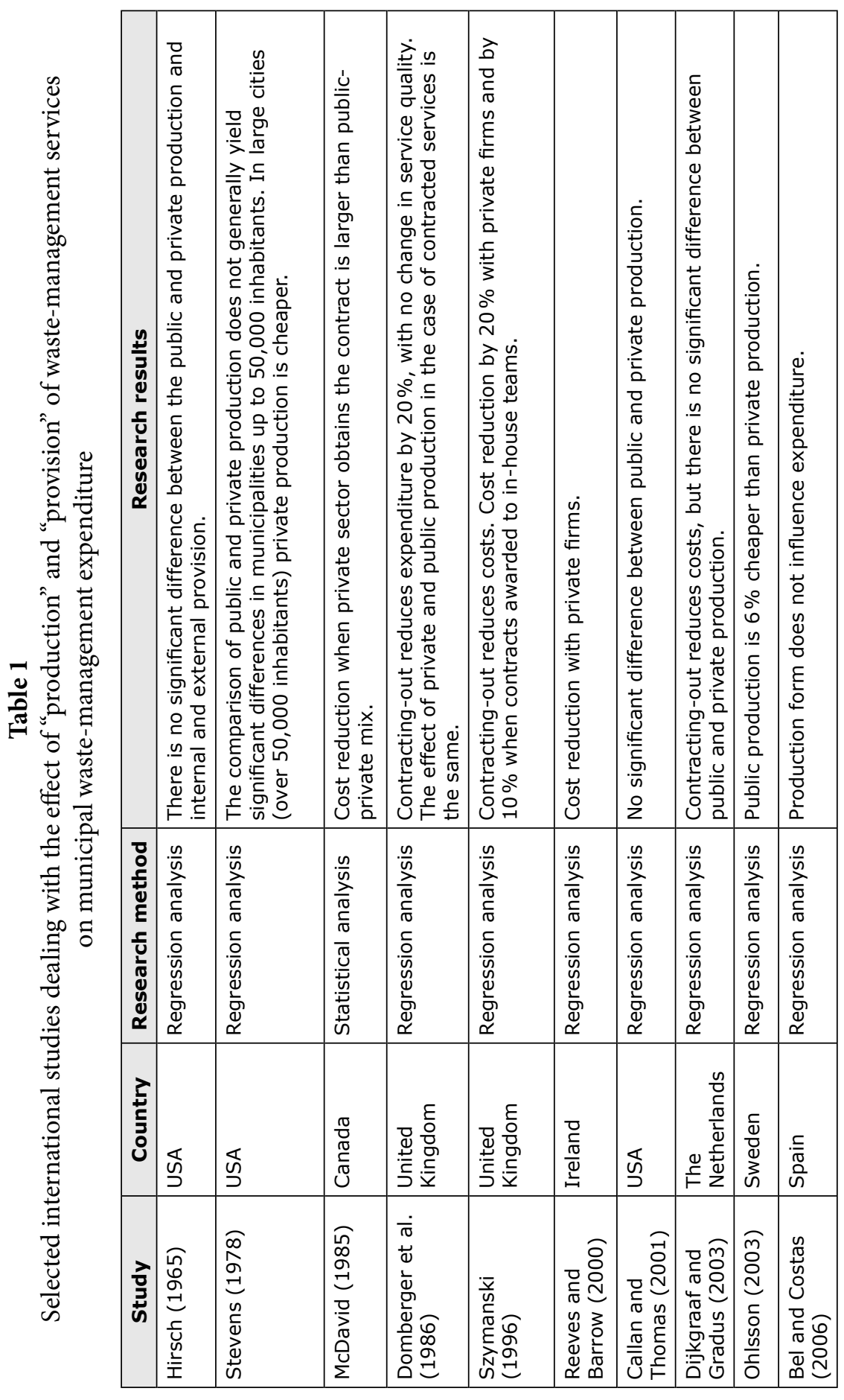




\begin{tabular}{|c|c|c|c|c|c|c|c|c|c|}
\hline 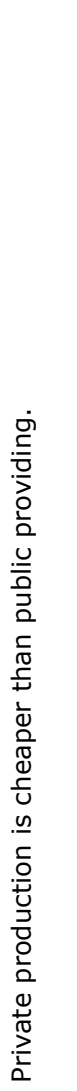 & 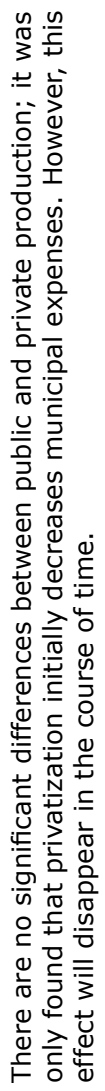 & 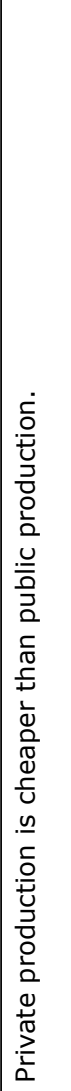 & 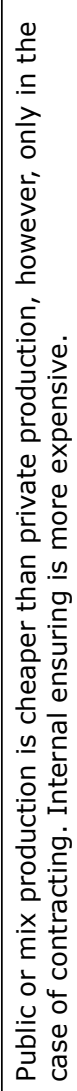 & 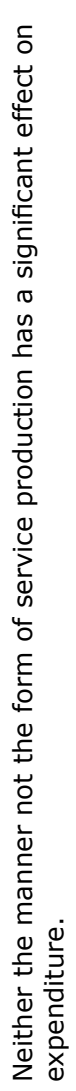 & 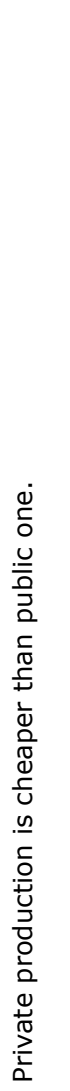 & 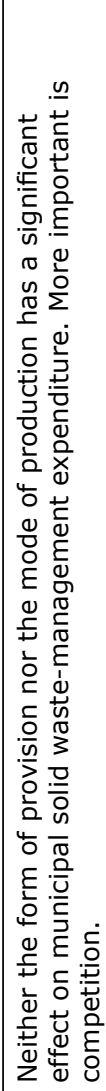 & 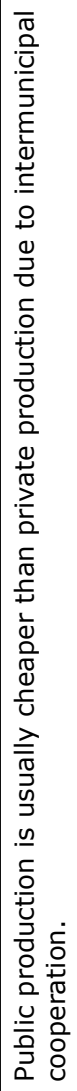 & 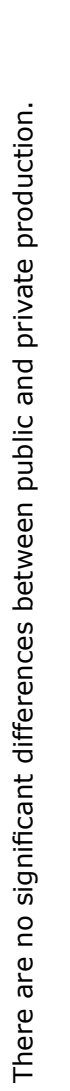 & 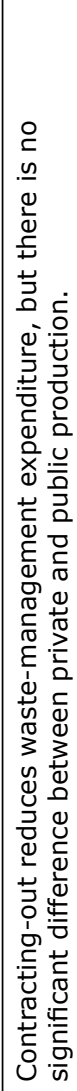 \\
\hline 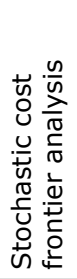 & 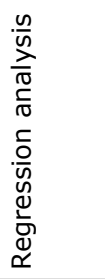 & 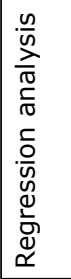 & 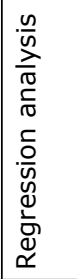 & 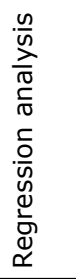 & 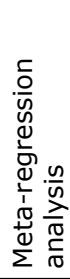 & 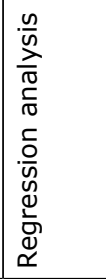 & 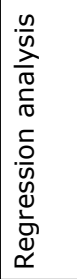 & 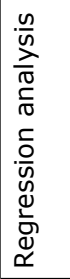 & 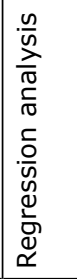 \\
\hline$\frac{d}{\frac{d}{2}}$ & 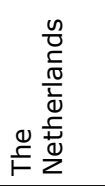 & $\begin{array}{l}\frac{5}{\pi} \\
\text { के } \\
\text { ñ }\end{array}$ & $\frac{\lambda}{\sqrt[N]{ \pm}}$ & $\begin{array}{l}\frac{5}{\pi} \\
\text { ñ }\end{array}$ & $\begin{array}{l}\text {. } \\
\text { त̃ } \\
\text { ñ }\end{array}$ & $\begin{array}{l}\frac{5}{\pi} \\
\stackrel{0}{0} \\
\text { in }\end{array}$ & $\begin{array}{l}\text {.5 } \\
\text { 离 }\end{array}$ & $\begin{array}{l}\frac{5}{\pi} \\
\text { ñ }\end{array}$ & 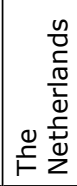 \\
\hline 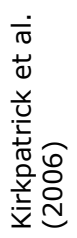 & 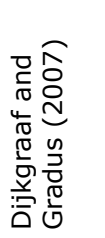 & 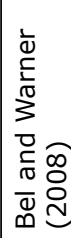 & 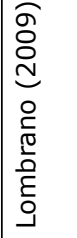 & 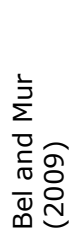 & 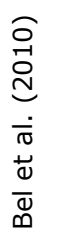 & 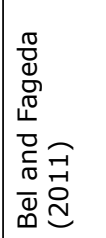 & 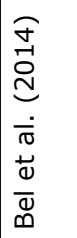 & 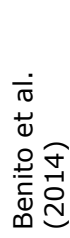 & 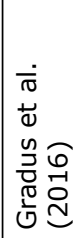 \\
\hline
\end{tabular}




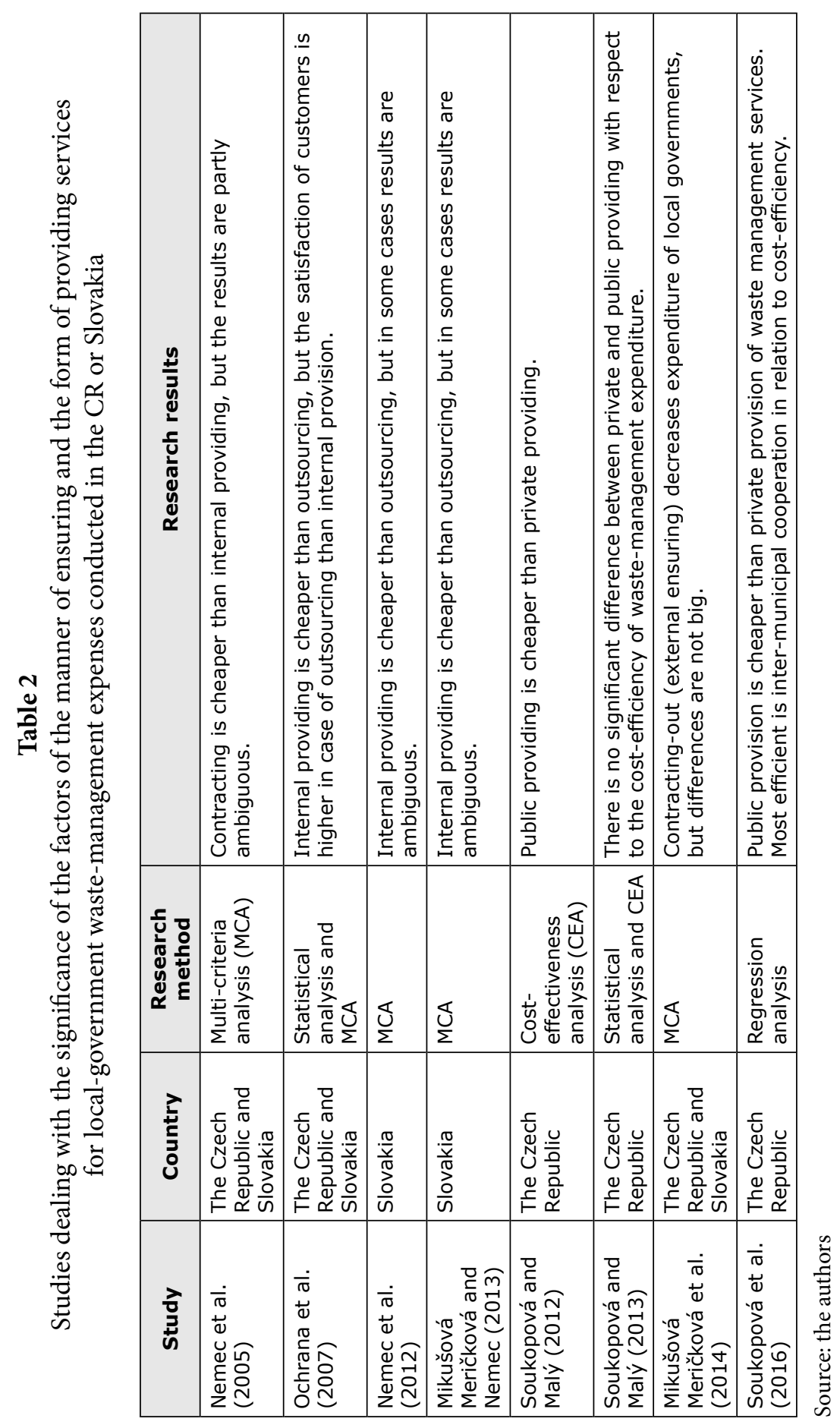




$$
\text { MSWEpc }=f\left(\text { Out,Rec,Dens, Form, Mode,Coop, Hyb,Scale }{ }_{15} \text { Scale }_{50} \text { Land }\right)
$$

The dependent variable, which we shall call $M S W E p c$, is the total municipal waste-management expenditure per capita in the local governments of the South Moravian Region in the Czech Republic. It includes the collection, transportation and disposal or treatment and other waste management services. The total costs incurred by the local government are determined by the population of the municipality (therefore we study the expenses per population), and the variables influencing the expenses are as follows:

- Output (Out): The first explanatory variable is the quantity of waste generated in the local government, expressed in kilos per capita. We expect that the costs increase with the output, and we have based our assumption on existing evidence (Bel and Costas 2006; Dijkgraaf and Gradus 2003, 2007).

- Population density (Dens): We take population density, measured in inhabitants per square kilometre, as a municipal density indicator. A higher density could decrease the total waste cost, but, for instance, Bel and Mur (2009) noted that the higher concentration of population should lead to greater problems of traffic congestion because the final effect of the variable Dens is ambiguous.

- Percentage of recycling (Rec): This variable is defined as the amount of recycled waste per amount of total solid waste. We expect the costs to increase with the percentage of recycling, and we have based our assumption on existing evidence (McDavid 1985; Bel and Costas 2006).

- Form of provision (Form): This is the dummy variable for the form of provision of waste-management services that acquires value 1 in case of internal provision and value 0 in case of outsourcing. Results of international studies in various countries of Europe, USA and also in the Czech Republic and Slovakia are ambiguous for this variable (see Tables 1 and 2). This is also a reason why the hypothesis for this variable is ambiguous.

- Mode of production (Mode): This variable captures the influence of either public or private production of the service on costs. It is constructed as a dummy variable and takes the value 1 if the service is delivered by a public company and the value 0 in the case of private production. A public company is defined as a company with public ownership of more than $50 \%$. The expected effect is ambiguous: as it has been already pointed out, some researchers have found a negative relation between public production and the costs, some others have found a negative relation between private production and the costs, while others have not found any conclusive evidence at all (see Tables 1 and 2).

- Inter-municipal cooperation (Coop): This is the dummy variable expressing the inter-municipal cooperation that acquires the value 1 for inter-municipal cooperation, otherwise it acquires the value 0 . The hypothesis for this variable is a 
negative correlation, which is also confirmed by a number of the studies mentioned above (for example Bel and Costas 2006; Sørensen 2007; Bel and Mur 2009; Dijkgraaf and Gradus 2013; Zafra-Gómez et al. 2013; Gradus et al. 2014, etc.).

- Hybrid (Mixed) form (Hyb): Impact of the hybrid (mixed) form of waste-collection companies is examined in a number of recent studies (e.g. Warner and Hefetz 2012; Gradus et al. 2014; Gradus et al. 2016). In order to assess the influence of the hybrid form of enterprises on waste-management expenditure we use variable $H y b$ as a dummy variable that takes value 1 if the waste-management services are provided by the mixed form of enterprise (Public-Private partnership) and value 0 otherwise. The hypothesis for this variable is ambiguous. International studies reach various conclusions in this matter (Warner and Hefetz 2012; Gradus et al. 2014; Gradus et al. 2016).

- Economies of scale (Scale ${ }_{15}$, Scale ${ }_{50}$ ): These variables capture the influence of economies of scale on municipal waste-management expenditure. It is constructed as a dummy variable and takes the value 1 if the collection company earns the economies of scale at collection area with population over 15,000 inhabitants and the value 0 otherwise. Results in the literature mostly indicate that lowpopulated municipalities saw scale economies that were either slight (Stevens 1978) or non-existent (Hirsch 1965; Callan and Thomas 2001), and hardly any work reported scale economies for highly populated municipalities. Since previous results on scale economies are mixed, this hypothesis is ambiguous.

- Landfill in the municipality (Land): Transportation costs between the municipality and the disposal place represents an important part of the service's costs. As in Callan and Thomas (2001) and Bel and Costas (2006), we consider a dummy variable showing the existence of a landfill in the municipality. It takes value 1 if the landfill is in the municipality and 0 otherwise. As in Bel and Costas (2006) we expect a negative effect of this variable.

The analysis, which involved both explorative-data analysis and multiple-regression analysis, was conducted at the municipality level and used data from the year 2015. We used the software packages Microsoft Excel 2011 and STATISTICA for the analyses. The following table shows descriptive statistics of the individual variables. 
Table 3

Descriptive statistics of variables in the model (Source: The authors)

\begin{tabular}{|l|c|c|c|c|}
\hline \multicolumn{1}{|c|}{ Variables } & Mean & Min & Max & $\begin{array}{c}\text { Standard } \\
\text { deviation }\end{array}$ \\
\hline MSWEpc & 619.6225 & 47.0464 & $2,774.2722$ & 155.9774 \\
\hline Out & 282.9432 & 1.0798 & $1,373.6181$ & 140.9885 \\
\hline Dens & 1.0595 & 0.0756 & 21.2252 & 1.2945 \\
\hline Rec & 0.2390 & 0.0262 & 0.9893 & 0.1413 \\
\hline Form & 0.0122 & 0.0000 & 1.0000 & 0.1097 \\
\hline Mode & 0.4407 & 0.0000 & 1.0000 & 0.4969 \\
\hline Coop & 0.3267 & 0.0000 & 1.0000 & 0.4694 \\
\hline Hyb & 0.0988 & 0.0000 & 1.0000 & 0.2986 \\
\hline Scale50 & 0.6763 & 0.0000 & 1.0000 & 0.4682 \\
\hline Scale15 & 0.8739 & 0.0000 & 1.0000 & 0.3323 \\
\hline Land & 0.0213 & 0.0000 & 1.0000 & 0.1444 \\
\hline
\end{tabular}

\section{Results and discussion}

If we interpret the results of the regression analysis shown in Table 4, it is obvious that the "production-provision" dilemma is not a dilemma with an effect on reducing waste-management expenditures in local governments in the Czech Republic. The statistically relevant variables are output, inter-municipal cooperation and hybridity. An interesting point is that other variables are not statistically significant with an effect on municipal waste-management expenditure.

The results in Table 4 show that the municipal waste-management expenditure per capita is influenced by the outcome (the municipal waste quantity per capita). Here, the hypothesis was confirmed that a higher outcome increases municipal expenditure per capita. It is interesting that the hypothesis for the recycling ratio increasing the expenditure per capita was not confirmed, and this variable has no significant effect on expenditure. This may be related to the reporting obligations of local governments, where some local governments (especially those in very small municipalities up to 500 inhabitants) fulfil this obligation sporadically or not at all and only provide data on the amount of total waste.

On the contrary, the result as regards the population density is surprising. This variable does not have sufficient statistical significance; however, it becomes evident that it influences expenditure and that the expenditures per capita of the local governments with a higher housing and population density are lower. The form of pro- 
vision as well as the mode of production are also statistically insignificant variables according to our results (Table 4). It confirms the ambiguity of our expectations, which are based on earlier studies. In these studies different authors came to contradictory concluding statements linked to the potential influence of both the mode of production and the form of provision, and we have not arrived at a clear output to support any of the competing hypotheses. In other words, due to a lack of statistical significance in the relevant results we cannot properly answer RQ3.

\section{Table 4}

Empirical results of the regression analysis (the OLS model) for the dependent variable of the waste management expenditure per capita

$$
(\mathrm{n}=658, \mathrm{R}=0.4841, \mathrm{R} 2=0.2584)
$$

\begin{tabular}{|c|c|c|c|c|c|c|}
\hline Variable & Coefficient & $\begin{array}{l}\text { Standard } \\
\text { error }\end{array}$ & t-share & $p$-value & $\begin{array}{l}\text { Hypothesis } \\
\text { (correlation) }\end{array}$ & $\begin{array}{c}\text { Fact } \\
\text { (correlation) }\end{array}$ \\
\hline Const & $\begin{array}{r}599.053 \\
* * *\end{array}$ & 66.0076 & 9.07550 & 0.00000 & & \\
\hline Out & $\begin{array}{r}0.364 \\
* * *\end{array}$ & 0.0914 & 3.97746 & 0.00007 & positive & Positive \\
\hline Dens & -10.033 & 3.4944 & -1.05674 & 0.29102 & ambiguous & $\begin{array}{l}\text { statistically } \\
\text { insignificant }\end{array}$ \\
\hline $\operatorname{Rec}$ & 33.392 & 84.7899 & 0.39382 & 0.69384 & positive & $\begin{array}{l}\text { statistically } \\
\text { insignificant }\end{array}$ \\
\hline Form & -191.774 & 113.5000 & -1.68964 & 0.09158 & ambiguous & $\begin{array}{l}\text { statistically } \\
\text { insignificant }\end{array}$ \\
\hline Mode & 6.667 & 44.1918 & 0.15087 & 6.66700 & ambiguous & $\begin{array}{l}\text { statistically } \\
\text { insignificant }\end{array}$ \\
\hline Coop & $\begin{array}{r}-91.964 \\
* *\end{array}$ & 45.7958 & -2.00812 & 0.00454 & ambiguous & Negative \\
\hline$H y b$ & $\begin{array}{r}174.243 \\
* * *\end{array}$ & 41.7529 & 4.17318 & 0.00003 & ambiguous & Positive \\
\hline Scale50 & -27.566 & 30.6615 & -0.89905 & 0.36896 & ambiguous & $\begin{array}{c}\text { statistically } \\
\text { insignificant }\end{array}$ \\
\hline Scale15 & 14.304 & 47.4890 & 0.30121 & 0.76335 & ambiguous & $\begin{array}{l}\text { statistically } \\
\text { insignificant }\end{array}$ \\
\hline Land & 15.625 & 85.1769 & 0.18344 & 0.85451 & negative & $\begin{array}{l}\text { statistically } \\
\text { insignificant }\end{array}$ \\
\hline
\end{tabular}

Note: bold items are statistically significant.

Source: The authors.

Although there is a mutual correlation between two variables - namely hybrid (mixed) form and inter-municipal cooperation - while the inter-municipal cooperation contributes to savings of the average waste-management expenditure, mixed ownership is rather connected with an increase of the mentioned expenditure. The 
result for the mixed form of waste-management service production is very surprising because, according to our results, it increases municipal waste-management costs by almost $30 \%$ of the average expenditure.

These results are partially in contradiction with the results of Lombrano (2009), who points out that cost savings are lower when a contract is won by a private provider than a PPP provider or public provider. As is shown by our results the inclusion of the private element through the PPP contract into the waste management does not necessarily lead to higher efficiency.

The inter-municipal cooperation in the field of waste management is of a voluntary nature in the Czech Republic, and therefore one can find several cooperation forms which are used for this purpose by the relevant local governments. Taking into account Oakerson's (1999) typology, alongside the private contracting, where the local governments enter into agreements with external private-service providers and outsource the service(s), the local governments which have been included into our sample use especially the joint provisions/productions of the service by the partially autonomous institutions. In fact, almost two-thirds of the examined local governments have entered some form of inter-municipal cooperation, and from this perspective this cooperation in the field of waste management can be described as a common phenomenon in the Czech Republic.

Obviously, the popularity of the inter-municipal cooperation in the field of waste management does not automatically mean that a cooperation-based design of delivery of this service is the best one also in terms of efficiency. However, taking into account our empirical results (Table 4 presents the results obtained from the estimation of the equation for the sample) it seems, that waste management belongs to the local services where the provision by means of various cooperation forms leads to much higher efficiency than its production.

Speaking of the savings through the inter-municipal cooperation, it seems that the local governments are capable of finding a way to decrease the waste-management expenditure. To be more precise, our results show that the inter-municipal cooperation decreases municipal waste-management expenditure by almost $15 \%$ of the average expenditure. In addition, a cooperative behaviour of the local governments is supported also by the fact that in-house provision or production is always less efficient than other forms of this service delivery.

As has been estimated, the explanatory variables have confirmed our assumptions, e.g. a higher density decreases the total waste-management expenditure, the recycling increases the total waste-management expenditure, etc. Nevertheless, a surprising result has been achieved by the variable called distance to landfill/incinerator. Despite the fact that a positive dependency was expected in compliance, for instance, with Callan and Thomas (2001), Ohlsson (2003), Bel and Costas (2006) or Dijkgraaf and Gradus (2006), the results have confirmed rather a negative de- 
pendency. This result may indicate a more significant role of a fee for use of a landfill/incinerator than the distance.

\section{Conclusions and implications for practice}

Our results lead us to a few conclusions. As for RQ1, the Czech local governments undoubtedly prefer the position of providers in the field of local waste management, because a clear majority of them are involved in various inter-municipal cooperation forms also in the field of waste management. One would guess that their main motivation is either overcoming the shortages linked to the highly fragmented structure of the local governments (according to Klimovský 2014, who conducted his research in the fragmented regions of Slovakia, this is one of the important reasons why the small local governments look for mutual collaboration) or supporting the insufficient capacities of too small local governments. However, further research aimed at the reasons of cooperation between the local governments in the fields of local waste management is needed in order to confirm or reject this hypothesis.

Our results linked to RQ2 are pretty unambiguous, because whenever some local government tries to be a producer of the waste-collection services, it is always a less efficient solution. In comparison, inter-municipal cooperation seems to be very effective and at the same time an efficient solution for the local governments in the highly fragmented environment (compare with Franzke et al. 2016). However, this is a somewhat tricky conclusion. On the one hand, the inter-municipal cooperation has proved to unequivocally influence decreases in waste-management expenditure (this result is similar to, e.g., Bel et al. 2014). On the other hand, intermunicipal cooperation forms often overlap with hybrid forms, and many inter-municipal companies are co-owned by both local governments and private companies within various public-private partnerships. From this point of view, our finding is an important contribution to present academic debate because alongside with the results by Gradus et al. (2016) it challenges results of some previous research.

Concerning RQ3, unfortunately, we cannot provide data which could allow us to undoubtedly answer this question. Regardless of this fact, it seems that neither a form of provision nor a mode of production is a key factor of cost-efficiency in the field of local waste management in the Czech Republic.

At this point we want to stress that we are aware of limits of our research presented in this article. In spite of a large research-sample size, we have conducted our research only in one of the Czech regions. Speaking on the inter-municipal cooperation, our data refer only to the field of waste management, and therefore further research activities aimed at the delivery of other local services should be conducted in order to discuss the "production-provision" dilemma at the local level in a more detailed way. Furthermore, we have not compared the Czech data with the data from other countries, and since our conclusions are rather country-based, 
it is necessary to understand them in a broader context of existing as well as forthcoming research.

Last but not least, regardless of the abovementioned limits, there are two important lessons to be learnt for practitioners. First, whenever the local governments decide to produce the waste-collection services in-house, it is always the less efficient solution in comparison with being in the position of provider but not producer. But provision includes several different options according to Oakerson (1999), and our results do not favour any of them. Therefore it is up to the practitioners who must consider every single case separately, and they cannot rely exclusively on the previous experience of other local governments.

And second, it is clear that the local governments prefer collaboration with other local governments. From this perspective it is no surprise that inter-municipal cooperation is considered a sufficient measure. In addition, our results allow us to support also the statement that inter-municipal cooperation is often accompanied with a decrease of average costs. However, as was already stressed by Lackowska (2009), inter-municipal cooperation is not a panacea. The point is that one size does not fit all. For instance, if practitioners and municipal representatives look for "an optimal" population size, a high diversity of local services leads us to different recommendations (cf. Klimovský 2014; Soukopová et al. 2016). Taking this fact into account, it is impossible to state how large and how many local governments must cooperate in order to achieve cost-efficiency in all cases of delivery of local services they are responsible for. More precisely, while collaborating local governments can be more efficient in the delivery of one service, but at the same time they may fail to achieve efficiency in the delivery of another service.

\section{Acknowledgement}

This article has been elaborated as one of the outcomes of the research project "Unfair competition and other economic factors influencing the efficiency of the provision of public services, the Czech Science Foundation", Reg. No. GA15-08032S.

\section{References}

Bel, Germà and Antón Costas. 2006. "Do Public Sector Reforms get Rusty? Local Privatization in Spain." The Journal of Policy Reform 9(1), 1-24.

Bel, Germà and Xavier Fageda. 2011. "Big Guys Eat Big Cakes: Firm Size and Contracting in Urban and Rural Areas." International Public Management Journal 14(1), 4-26. 
Bel, Germà, Xavier Fageda and Melania Mur. 2014. "Does Cooperation Reduce Service Delivery Costs? Evidence from Residential Solid Waste Services." Journal of Public Administration Research and Theory 24(1), 85-107.

Bel, Germà, Xavier Fageda and Mildred E. Warner. 2010. "Is Private Production of Public Services Cheaper than Public Production? A Meta Regression Analysis of Solid Waste and Water Services." Journal of Policy Analysis and Management 29(3), 553-577.

Bel, Germà and Melania Mur. 2009. "Intermunicipal Cooperation, Privatization and Waste Management Costs: Evidence from Rural Municipalities." Waste Management 29(10), 2772-2778.

Bel, Germà and Mildred Warner. 2008. "Does Privatization of Solid Waste and Water Services Reduce Costs? A Review of Empirical Studies." Resources, Conservation and Recycling 52(12), 1337-1348.

Benito, Bernardino, José Solana and María-Rocío Moreno. 2014. "Explaining Efficiency in Municipal Services Providers." Journal of Productivity Analysis 42(3), 225-239.

Callan, Scot J. and Janet M. Thomas. 2001. "Economies of Scale and Scope: A Cost Analysis of Municipal Solid Waste Services." Land Economics 77(4), 548-560.

Csachová, Stela and Janette Nesorová-Dická. 2011. “Territorial Structure of Local Government in the Slovak Republic, the Czech Republic and the Hungarian Republic: Comparative View.” Geografický ćasopis 63(3), 209-225.

Dijkgraaf, Elbert and Raymond Gradus. 2003. "Cost Savings of Contracting out Refuse Collection.” Empirica 30(2), 149-161.

Dijkgraaf, Elbert and Raymond Gradus. 2007. "Collusion in the Dutch Waste Collection Market." Local Government Studies 33(4), 573-588.

Dijkgraaf, Elbert and Raymond Gradus. 2013. "Cost Advantage Cooperations Larger than Private Waste Factors." Applied Economics Letters 20(7), 702-705.

Domberger, Simon, Shirley A. Meadowcroft and David J. Thompson. 1986. "Competitive Tendering and Efficiency: The Case of Refuse Collection." Fiscal Studies 7(4), 69-87.

Franzke, Jochen, Daniel Klimovský and Uroš Pinterič. 2016. "Does Inter-Municipal Cooperation Lead to Territorial Consolidation? A Comparative Analysis of Selected European Cases in Times of Crisis." In Sabine Kuhlmann and Geert Bouckaert (eds). Local Public Sector Reforms in Times of Crisis: National Trajectories and International Comparisons. Houndmills/New York: Palgrave Macmillan, 81-98. 
Gradus, Raymond, Elbert Dijkgraaf and Martijn Schoute. 2016. "Is there still Collusion in the Dutch Waste Collection Market?" Local Government Studies 42(5), 689-697.

Gradus, Raymond, Elbert Dijkgraaf and Mattheus Wassenaar. 2014. "Understanding Mixed Forms of Refuse Collection, Privatization, and Its Reverse in the Netherlands." International Public Management Journal 17(3), 328-343.

Grafenauer, Božo and Mirko Klarić. 2011. "Alternative Service Delivery Arrangements at the Municipal Level in Slovenia and Croatia." Lex localis - Journal of Local Self-Government 9(1), 67-83.

Hirsch, Werner Z. 1965. "Cost Functions of an Urban Government Service: Refuse Collection." The Review of Economics and Statistics 1965, 87-92.

Kirkpatrick, Colin, David Parker and Yin-Fan Zhang. 2006. “An Empirical Analysis of State and Private-Sector Provision of Water Services in Africa." The World Bank Economic Review 20(1), 143-163.

Klimovský, Daniel. 2014. Inter-municipal Cooperation in Slovakia: The Case of Regions with Highly Fragmented Municipal Structure. Novo Mesto: Faculty of Organization Studies.

Lackowska, Marta. 2009. "Why is Voluntary Co-operation Condemned to Failure? Reflections on the Polish and German Background." Lex Localis - Journal of Local Self-Government 7(4), 347-369.

Lember, Veiko. 2004. "Limiting Aspects of Contracting out in Transitional Countries: The Case of Estonian Prisons." Public Administration \& Development 24(5), 425-435.

Lombrano, Alessandro. 2009. "Cost Efficiency in the Management of Solid Urban Waste." Resources, Conservation and Recycling 53(11), 601-611.

McDavid, James C. 1985. “The Canadian Experience with Privatizing Residential Solid Waste Collection Services." Public Administration Review 45(5), 602-608.

Mikušová Meričková, Beáta and Juraj Nemec. 2013. “Factors Determining the Success of Contracting Local Public Services: Waste Collection and Waste Disposal, Management of Cemeteries in Slovakia." Lex Localis 11(3), 375-386.

Mikušová Meričková, Beáta, Juraj Nemec and Jana Soukopová. 2014. “The Economics of Waste Management: Evidence from the Czech Republic and Slovakia." Lex Localis - Journal of Local Self-Government 12(3), 431-449.

Nemec, Juraj, Beáta Meričková and Leos Vitek. 2005. "Contracting-out at Local Government Level: Theory and Selected Evidence from Czech and Slovak Republics." Public Management Review 7(4), 638-647. 
Nemec, Juraj, Beáta Mikušová Meričková and Zuzana Vozárová. 2012. "Management of Contracting Public Services and its Quality in Slovakia." NISPAcee Journal of Public Administration and Policy 1, 55-74.

Oakerson, Ronald J. 1999. Governing Local Public Economies. Oakland: ICS Press.

Ochrana, František, Markéta Fantová Šumpíková, Jan Pavel, Juraj Nemec, Beáta Mikušová Meričková, Stanislav Klazar and Pavel Rousek. 2007. Efektivnost zabezpečování vybraných veřejných služebna úrovni obcí. Praha: Oeconomica.

Ochrana, František and Martin Nekola. 2009. "Economic Evaluation of Public Programs.” Ekonomický časopis 2009(5), 458-474.

Ohlsson, Henry. 2003. "Ownership and Production Costs: Choosing between Public Production and Contracting-Out in the Case of Swedish Refuse Collection." Fiscal Studies 24(4), 451-476.

Pavel, Jan and Emília Sičáková-Beblavá. 2008. “Transparency of Public Procurement Market in the Czech Republic and Slovakia.” Ekonomický časopis 2(56), $168-181$.

Reeves, Eoin and Michael Barrow. 2000. "The Impact of Contracting out on the Costs of Refuse Collection Services: The Case of Ireland." Economic and Social Review 31(2), 129-150.

Simões, Pedro and Rui Cunha Marques. 2012. "On the Economic Performance of the Waste Sector: A Literature Review." Journal of Environmental Management 106, 40-47.

Sørensen, Rune J. 2007. "Does Dispersed Public Ownership Impair Efficiency? The Case of Refuse Collection in Norway." Public Administration 85(4), 1045-1058.

Soukopová, Jana and Ivan Malý. 2013. "Competitive Environment in Waste Management and its Impact on Municipal Expenditures." Acta universitatis agriculturae et silviculturae Mendelianae Brunensis 61(4), 1113-1119.

Soukopová, Jana and Ivan Malý. 2012. "Vliv konkurence na výši výdajů na nakládání s odpady obcí Jihomoravského kraje." In Waste Forum, No. 4. Praha: CEMC, 173-183.

Soukopová, Jana, Juraj Nemec, Lenka Matějová and Michal Struk. 2014. "Municipality Size and Local Public Services: Do Economies of Scale Exist?" NISPAcee Journal of Public Administration and Policy 7(2), 151-171.

Soukopová, Jana, František Ochrana, Daniel Klimovský and Beáta Mikušová Meričková. 2016. "Factors Influencing the Efficiency and Effectiveness of Municipal Waste Management Expenditure." Lex Localis - Journal of Local Self-Government 14(3), 361-380. 
Soukopová, Jana and Gabriela Vaceková. 2015. "Competition and Municipal Waste Management Expenditure: Evidence from the Czech Republic, Olomouc Region." Scientific Papers of the University of Pardubice, Series D 22(35), 128-138.

Stevens, Barbara J. 1978. "Scale, Market Structure, and the Cost of Refuse Collection." The Review of Economics and Statistics 60(3), 438-448.

Szymanski, Stefan. 1996. “The Impact of Compulsory Competitive Tendering on Refuse Collection Services.” Fiscal Studies 17(3), 1-19.

Warner, Mildred E. and Amir Hefetz. 2012. "Insourcing and Outsourcing: The Dynamics of Privatization among US Municipalities 2002-2007." Journal of the American Planning Association 78(3), 313-327.

Wollmann, Hellmut. 2011. "Provision of Public Services in European Countries: From Public/Municipal to Private and Reverse?" Croatian and Comparative Public Administration 11(4), 889-910.

Wollmann, Hellmut, Ivan Koprić and Gérard Marcou (eds). 2016. Public and Social Services in Europe: From Public and Municipal to Private Sector Provision. Houndmills/New York: Palgrave Macmillan.

Zafra-Gómez, Jose L., Diego Prior, Anna M. P. Díaz and Antonio M. López-Hernández. 2013. "Reducing Costs in Times of Crisis: Delivery Forms in Small and Medium Sized Local Governments' Waste Management Services.” Public Administration 91(1), 51-68. 